\title{
Variations in the Physicochemical Water Parameters and Phytoplankton Community in Coastal Water of Kudat, Sabah, Malaysia
}

\author{
Mezzy Rynee Romin, Sujjat Al Azad*, Ejria Saleh \\ Borneo Marine Research Institute, University Malaysia Sabah, Kota Kinabalu, Malaysia \\ Email: ^Sujjat@ums.edu.my
}

How to cite this paper: Romin, M. R., Al Azad, S., \& Saleh, E. (2021). Variations in the Physicochemical Water Parameters and Phytoplankton Community in Coastal Water of Kudat, Sabah, Malaysia. Journal of Geoscience and Environment Protection, 9, 86-99. https://doi.org/10.4236/gep.2021.97006

Received: June 17, 2021

Accepted: July 19, 2021

Published: July 22, 2021

\section{Copyright $\odot 2021$ by author(s) and} Scientific Research Publishing Inc. This work is licensed under the Creative Commons Attribution International License (CC BY 4.0).

http://creativecommons.org/licenses/by/4.0/

\begin{abstract}
This study was conducted to observe the abundance and distribution of phytoplankton and temporal and spatial variation physico-chemical water parameters in coastal water of Kudat, Sabah, Malaysia. Water samples and in-situ water quality parameters were taken from five selected locations from May 2019 to February 2020. The sampling location was selected based on human-induced activities such as Marina Resort's Jetty (ST1), Sabah Ports' Jetty (ST2), aquaculture cage/pent (ST3), river's mouth (ST4) and Landung Ayang's water village (ST5). Water parameters: $\mathrm{pH}$, salinity (ppt), dissolved oxygen $(\mathrm{mg} / \mathrm{L})$ temperature $\left({ }^{\circ} \mathrm{C}\right)$ and depth $(\mathrm{m})$ were recorded once every month from the selected station. Identification of phytoplanktonic species and cell density (cell $/ \mathrm{mL}$ ) were determined from collected water samples. Significant differences $(p<0.05)$ between physicochemical parameters to months were observed during the study period. However, in spatial variations, significant differences $(p<0.05)$ of $\mathrm{pH}$, dissolved oxygen $(\mathrm{mg} / \mathrm{L})$ and temperature $\left({ }^{\circ} \mathrm{C}\right)$ observed. A total of 21 phytoplankton species were identified from the study area, where 4 species belonged to Dinophyceae (HABs blooming species) and 17 species belonged to Bacillariophyceae. The influences of physicochemical water parameters were not significant in phytoplankton diversity and abundance. In addition to these parameters, the nutrients in the water might have important roles in the blooming of phytoplankton, which are essential and vital to address in this type of research.
\end{abstract}

\section{Keywords}

Physicochemical Water Parameters, Phytoplankton, Coastal Water, Temporal and Spatial 


\section{Introduction}

Variability in physical and chemical water parameters, like temperature, $\mathrm{pH}$, salinity, dissolved oxygen concentration and depth, and nutrient concentrations are affected by both natural and human processes. Human induced activities, such as agricultural runoff, sewage and municipal effluents for residential areas and industrial waste are the ultimate sources of pollution that lead to change the water quality parameters (USEPA, 1998). Integrated physicochemical parameters are important for expertise in the sustainable development process and for management of healthy marine ecosystem (Kennish, 2000). To assess the pollution aquatic ecosystem, the basic information of physicochemical parameters is crucially important. Water parameters of temperature, $\mathrm{pH}, \mathrm{DO}$, turbidity, salinity, and nutrient are used as indicator in the condition of the water ecosystem (Aknaf et al., 2017). Knowledge of quality water and its response to aquatic biodiversity are also essential in the management of fisheries resources to provide more economic and environmental balance ecosystem. Discharges of waste from human-induced activities either point sources or non-point sources are influences by surface runoff and water quality parameters vary with season depend on the climate of the specific region (Singh et al., 2004).

The most significant biological community in any aquatic system is phytoplankton, as the basis of the trophic chain (Sin et al., 1999). The structure, distribution, and species diversity of the phytoplankton population in the aquatic environment are determined by several physico-chemical parameters (Sin et al., 1999). Chemical and physical variables such as temperature, salinity, $\mathrm{pH}$, nitrate, nitrite, ammonia, silicate, and dissolve inorganic phosphate are widely influenced by spatial and temporal variations in phytoplankton distribution (Vajravelu et al., 2018). Sudden changes in physicochemical parameters have a significant effect on the distribution and abundance of many species of phytoplankton (Shekhar et al., 2008). Phytoplankton diversity and successions are usually indicative of the water quality; their changes in succession can be correlated with the change of the aquatic ecosystem and physicochemical parameters such as the influence of nutrient runoffs into the water (Zulkifly et al., 2020). In a coastal ecosystem, marine phytoplankton population is mostly depending on nutrients and physical parameters, while nutrient concentration was insignificant in altering the phytoplankton density at Kota Kinabalu Wetland, Sabah due to influences with the tidal water (Azad \& Jinau, 2020). On the other hand, similar environmental in-situ water parameters did not greatly affect the phytoplankton growth (Azad \& Jinau, 2020).

Kudat is coastal district in the northernmost of Sabah, Malaysia has been an important area for recreational site attraction of many visitors and an increasing number of permanent residents as well as known for its seafood industry. There has been a lot of interest in researching different factors affecting phytoplankton growth in relation to physicochemical attributes over the past few decades (Sharma \& Tiwari, 2018). However, there is still a lack of information about the physicochemical conditions specifically associated with the phytoplankton community 
in this study area. The aim of the study was to provide information of phytoplankton community and the parameters of physicochemical water parameters to increase our understanding of variation of distribution patterns in this area of study. The contributed scientific data about the water quality and checklist of phytoplankton will help to take proper management to maintain the healthy ecosystem in that coastal area.

\section{Methodology}

\subsection{Site Description}

Samplings were conducted in Kudat, at the northernmost of Sabah and are located facing the South China Sea and Sulu Sea (Figure 1). Five sampling stations were selected (Figure 2). Using the Global Positioning System (GPS), the location of the sampling stations was labelled (Table 1). Stations 1 and 2 were located along the jetty, where the depth of water ranged from 3 to 15 metres, while stations 3, 4 and 5 were roughly 1 to 10 metres high. Stations 1, 2 and 5 were situated in areas of high human density with exposure to anthropogenic influences. Station 3 was the pent of a sea cucumber and fish cage while Station 4 was located near the mouth of a river and was also near the Kudat Esplanade (a harbour for most of the ships and boats in Kudat).

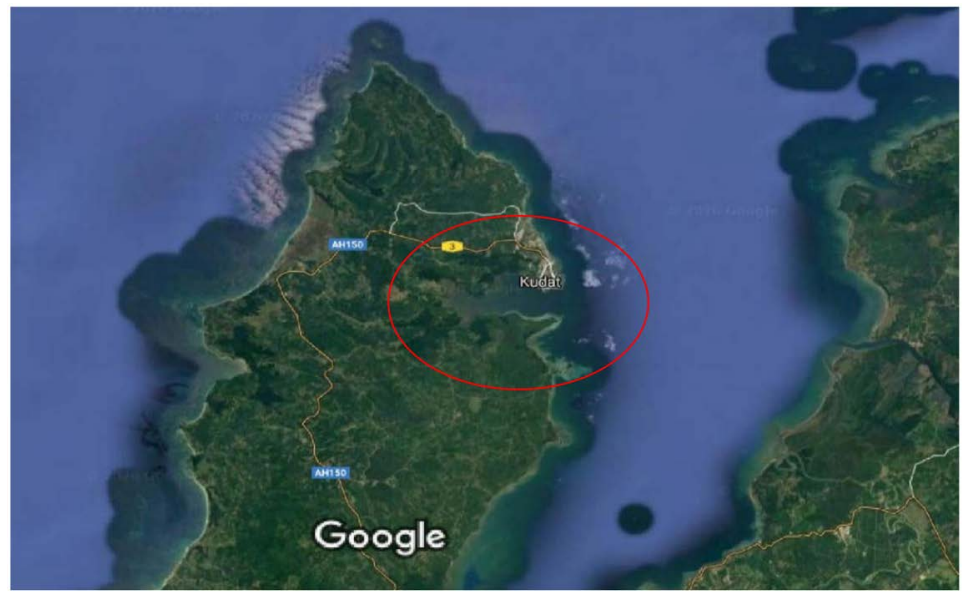

Figure 1. Study area within the coastal area of Kudat, Sabah, Malaysia.

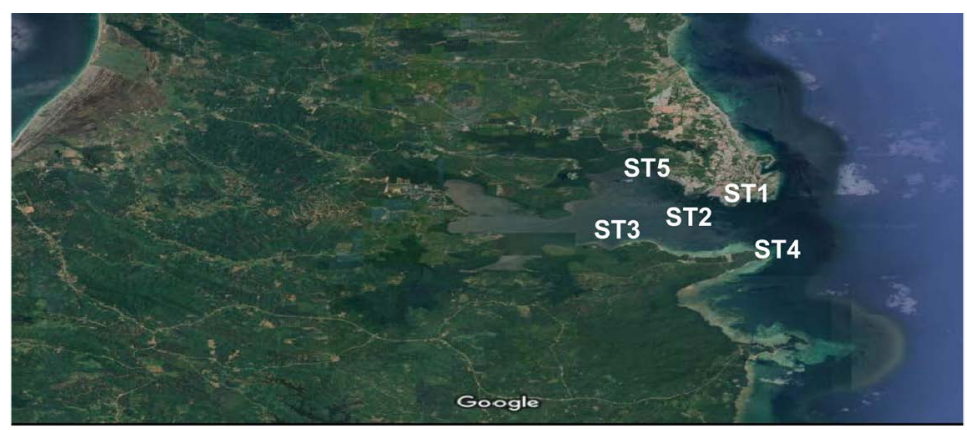

Figure 2. Location of stations within the coastal area of Kudat used to collect samples during the study period. 
Table 1. Coordinates of five sampling stations set with GPS.

\begin{tabular}{cc}
\hline Station & Coordinates (N/E) \\
\hline ST 1 & $06^{\circ} 53^{\prime} 29.4^{\prime \prime} / 116^{\circ} 51^{\prime} 26.7^{\prime \prime}$ \\
ST 2 & $06^{\circ} 52^{\prime} 44.3^{\prime \prime} / 116^{\circ} 50^{\prime} 48.3^{\prime \prime}$ \\
ST 3 & $06^{\circ} 52^{\prime} 47.4^{\prime \prime} / 116^{\circ} 51^{\prime} 26.7^{\prime \prime}$ \\
ST 4 & $06^{\circ} 52^{\prime} 10.4^{\prime \prime} / 116^{\circ} 51^{\prime} 32.9^{\prime \prime}$ \\
ST 5 & $06^{\circ} 51^{\prime} 45.7^{\prime \prime} / 116^{\circ} 49^{\prime} 39.1^{\prime \prime}$ \\
\hline
\end{tabular}

\subsection{Sampling for Phytoplankton Samples}

Samples of phytoplankton were collected from May 2019 until February 2020 in Kudat's water that covers smallest areas of the Coral Triangle Initiative (CTI) area. Initial planning was to collect samples for the period of May 2019 to May 2020, but due to pandemic of Covid-19 remaining sampling program was postponed. Phytoplankton were collected with plankton net $(20 \mu \mathrm{m}$ mesh size, radius $=0.52 \mathrm{~m}$ ). Samples were collected by hauling a net which covered 10 meters from each sampling station, to estimate water passed though the net. Collected samples were on spot preserved immediately with $3 \%$ formalin to avoid zooplankton grazing. In the laboratory zooplankton were separated by passing the sample through $60 \mu \mathrm{m}$ meshed sized filter and will be preserved with 5\% Lugol's solution for further analysis. Standard species identification was done in the laboratory by using Identifying Marine Phytoplankton book by C.R Tomas published in 1997. The Sedzwick rafter counting chamber was used to count the quantitative estimate of the phytoplankton using a compound microscope and the abundance was represented (cells/L) (Aktan et al., 2005). The total number of cells was counted according to the following information (Stirling, 1985) formula:

$$
N=(A \times 1000 \times C)(V \times F \times L)
$$

where:

$$
\begin{aligned}
& N=\text { No. of plankton cells per liter of original water; } \\
& A=\text { No. of plankton counted; } \\
& C=\text { Volume of final concentrate of the samples in milliliters }(\mathrm{mL}) ; \\
& V=\text { Volume of a field in cubic millimeter }(\mathrm{mm}) ; \\
& F=\text { No. of fields counted; } \\
& L=\text { Volume of original water in liters. }
\end{aligned}
$$

\subsection{Determination of Water's Physiochemical Parameters}

Multi-function environmental sensor (YSI multi-parameter probe, Model: Pro Plus, Geo-Hydro--Ocean Services) was used to measure the physiochemical parameters like $\mathrm{pH}$, temperature $\left({ }^{\circ} \mathrm{C}\right)$, dissolved oxygen $(\mathrm{mg} / \mathrm{L})$ and salinity $(\mathrm{ppt})$ values from each station of the study site. 


\subsection{Statistical Analysis}

The statistical analysis was performed using the SPSS Window Statistical Package (Version 23) to find out significant differences of the physicochemical water quality parameters and abundance of phytoplankton among the months and within the stations. One ways ANOVA and significance values were set at $p<$ 0.05 used in this study.

\section{Results}

\subsection{Temporal Variations}

The range of temporal variations in $\mathrm{pH}$, salinity (ppt), dissolved oxygen $(\mathrm{mg} / \mathrm{L})$, temperature $\left({ }^{\circ} \mathrm{C}\right)$ and depth $(\mathrm{m})$ were between $7.33 \pm 0.20$ to $8.20 \pm 0.17$ (Figure 3(a)), $29.37 \pm 0.09 \mathrm{ppt}$ to $32.71 \pm 0.47 \mathrm{ppt}$ (Figure $3(\mathrm{~b})$ ), $4.02 \pm 0.83 \mathrm{mg} / \mathrm{L}$ to $6.71 \pm 0.83 \mathrm{mg} / \mathrm{L}$ (Figure $3(\mathrm{c})$ ), $28.3^{\circ} \mathrm{C} \pm 0.26^{\circ} \mathrm{C}$ to $31.5^{\circ} \mathrm{C} \pm 0.33^{\circ} \mathrm{C}$ (Figure $3(\mathrm{~d})$ ) and $2.6 \pm 0.24 \mathrm{~m}$ to $3.7 \pm 0.26 \mathrm{~m}$ (Figure $3(\mathrm{e})$ ) respectively. However, there are significant.

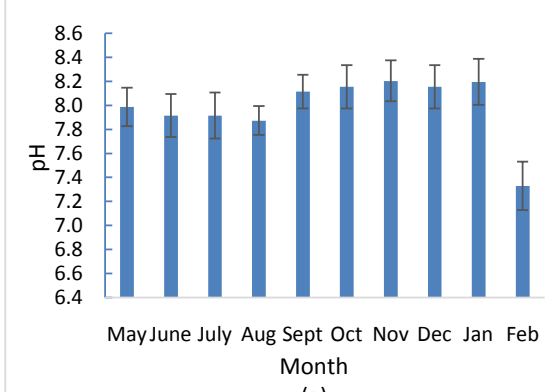

(a)

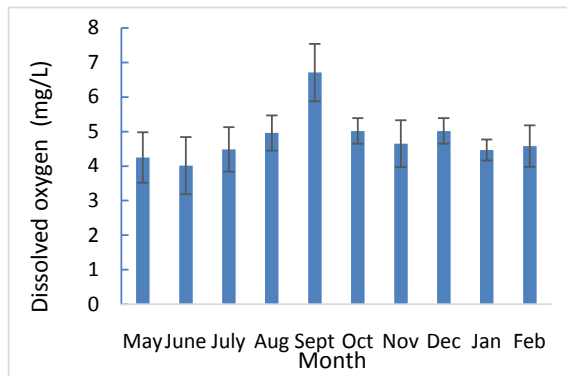

(c)

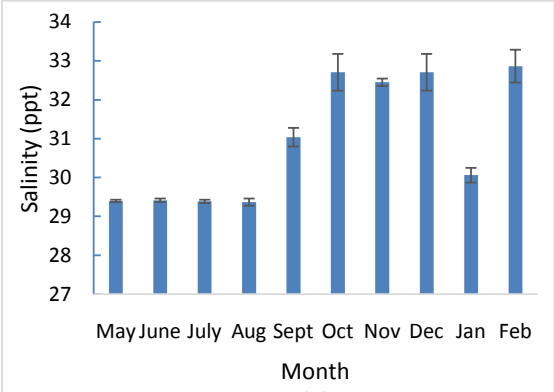

(b)

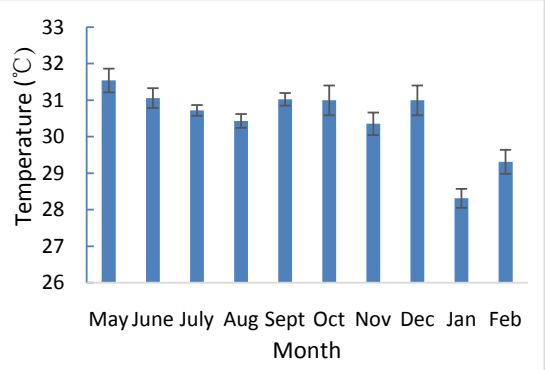

(d)

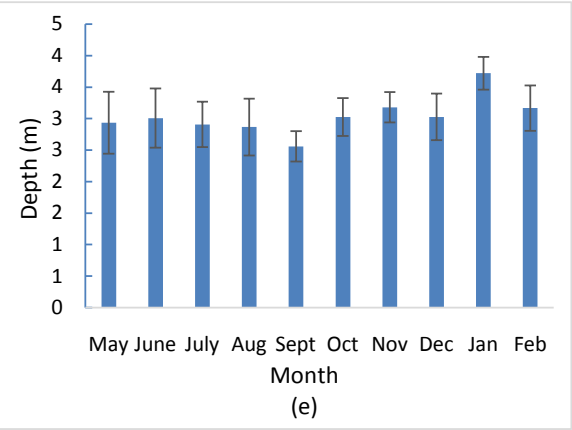

Figure 3. (a)-(e). The Temporal variations of physiochemical parameters (mean \pm sd.) in Kudat's coastal water from May 2019 to February 2020. 
However, there are significant differences $(p<0.05)$ between those physiochemical parameters among the months except for depth $(p>0.05)$.

\subsection{Spatial Variations}

The spatial ranges of $\mathrm{pH}$ salinity (ppt), dissolved oxygen $(\mathrm{mg} / \mathrm{L})$, temperature $\left({ }^{\circ} \mathrm{C}\right)$ and depth $(\mathrm{m})$ were $7.86 \pm 0.32$ to $8.13 \pm 0.26$ (Figure $4(\mathrm{a})$ ), $30.31 \pm 1.96$ ppt to $31.29 \pm 1.77 \mathrm{ppt}$ (Figure $4(\mathrm{~b})$ ), $4.33 \pm 1.06 \mathrm{mg} / \mathrm{L}$ to $5.38 \pm 0.81 \mathrm{mg} / \mathrm{L}$ (Figure $4(\mathrm{c})$ ), $30.3^{\circ} \mathrm{C} \pm 0.95^{\circ} \mathrm{C}$ to $30.6^{\circ} \mathrm{C} \pm 1.02^{\circ} \mathrm{C}$ (Figure $4(\mathrm{~d}$ )) and $1.7 \pm 0.21$ $\mathrm{m}$ to $5.0 \pm 0.39 \mathrm{~m}$ (Figure $4(\mathrm{e})$ ) respectively. However, there observed the significant difference $(p<0.05)$ of all those parameters among the stations.

\subsection{Phytoplankton Composition and Abundance}

A total of 21 phytoplanktonic species were identified in Kudat's coastal water from May 2019 to February 2020 (Table 2). The most dominant phytoplankton were from group Bascillariophyceae with 18 diatom species followed by Dinophyceae with 3 dinoflagellates species. The highest density of 112.31 cells/L of

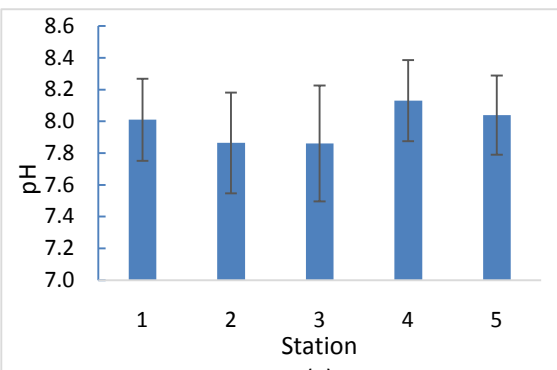

(a)

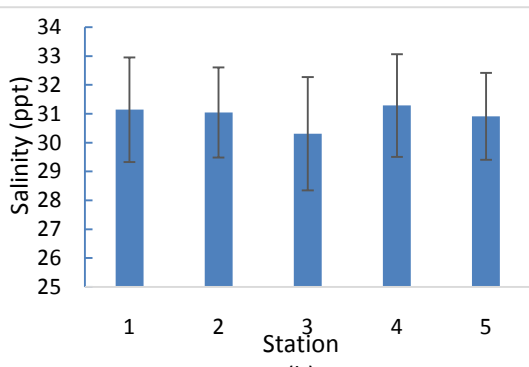

(b)
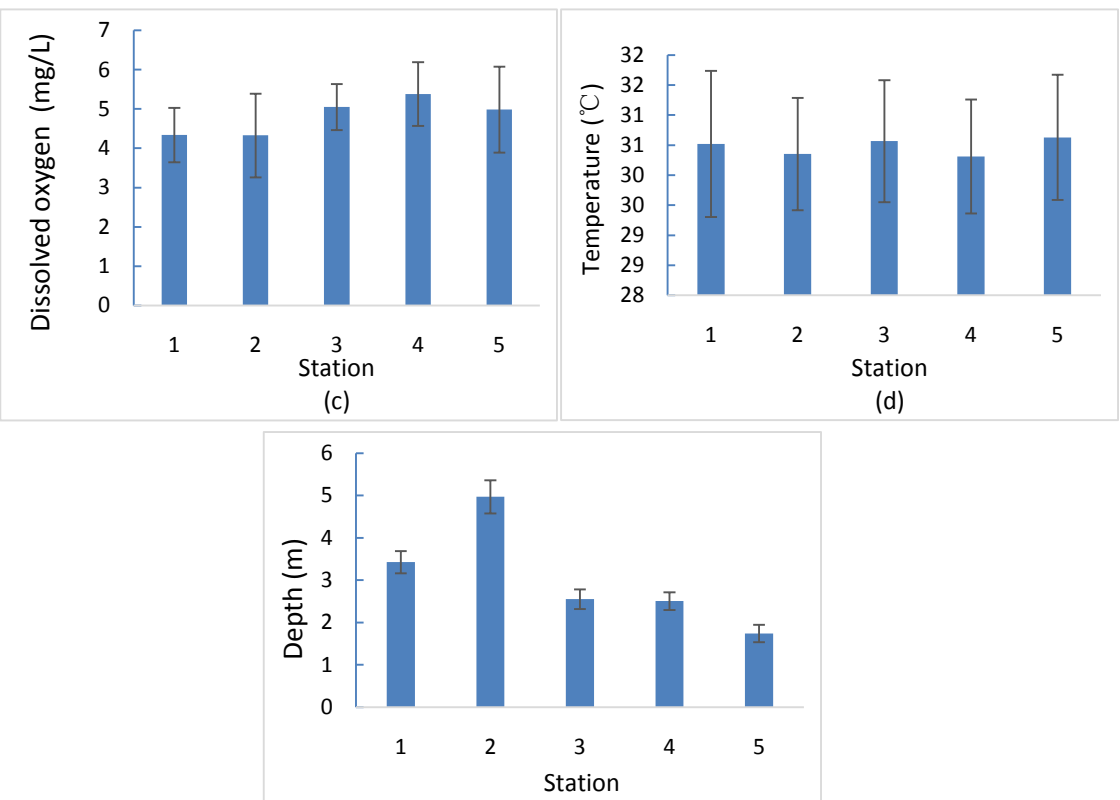

(e)

Figure 4. (a)-(e). The spatial variations of physiochemical parameters (mean \pm sd.) in Kudat's coastal water from May 2019 to February 2020. 
Table 2. Species of phytoplankton recorded in the coastal water of Kudat during study period.

\begin{tabular}{|c|c|c|c|c|}
\hline & Class & Phytoplankton species & $\begin{array}{c}\text { Total cells } \\
\text { (cells/L) }\end{array}$ & Percentage (\%) \\
\hline Diatom & Dinophyceae & Ceratium sp. & 112.31 & 30.46 \\
\hline Diatom & Bascillariophyceae & Nitzschia sp. & 38.02 & 10.31 \\
\hline Diatom & Bascillariophyceae & Coscinodiscus sp. & 29.41 & 7.97 \\
\hline Diatom & Bascillariophyceae & Thalassiothrix sp. & 25.57 & 6.93 \\
\hline Diatom & Bascillariophyceae & Thalassionema sp. & 25.41 & 6.89 \\
\hline Diatom & Bascillariophyceae & Pleurosigma sp. & 24.94 & 6.76 \\
\hline Dinoflagellate & Dinophyceae & Peridinium sp. & 23.78 & 6.45 \\
\hline Diatom & Bascillariophyceae & Navicula sp. & 20.63 & 5.59 \\
\hline Diatom & Bascillariophyceae & Rhizosolenia sp. & 14.69 & 3.98 \\
\hline Dinoflagellate & Dinophyceae & Prorocentrum sp. & 12.69 & 3.44 \\
\hline Diatom & Bascillariophyceae & Chaetoceros sp. & 11.78 & 3.19 \\
\hline Diatom & Bascillariophyceae & Entomoneis sp. & 10.56 & 2.86 \\
\hline Diatom & Bascillariophyceae & Asterionella sp. & 5.15 & 1.40 \\
\hline Diatom & Bascillariophyceae & Bacteriastrum sp. & 4.07 & 1.10 \\
\hline Dinoflagellate & Dinophyceae & Dinophysis sp. & 3.40 & 0.92 \\
\hline Diatom & Bacillariophyceae & Biddulphia sp. & 1.89 & 0.51 \\
\hline Diatom & Bascillariophyceae & Ditylum sp. & 1.48 & 0.40 \\
\hline Diatom & Bascillariophyceae & Thalassiosira sp. & 1.11 & 0.30 \\
\hline Diatom & Bascillariophyceae & Hemiaulus sp. & 0.81 & 0.22 \\
\hline Diatom & Bascillariophyceae & Climacodium sp. & 0.74 & 0.20 \\
\hline \multirow[t]{2}{*}{ Diatom } & Bascillariophyceae & Triceratium sp. & 0.34 & 0.09 \\
\hline & TOTAL & & 368.78 & 100 \\
\hline
\end{tabular}

Ceratium sp. was recorded during the study period and followed by Nitzschia sp. (38.02 cells/L), Coscinodiscus sp. (29.41 cells/L), Thalassiothrix sp. (25.57 cells/L), Thalassionema sp. (25.41 cells/L), Pleurosigma sp. (24.94 cells/L), and Peridinium sp. (23.78 cells/L).

The highest abundance of phytoplankton was observed during the month of December, January and February with the density of 929, 773 and 410 cells/L respectively. On the other hand, the lowest density of 206 cell/L phytoplanktonic abundance was recorded during the month of August in this study area (Figure $5(a))$. However, significant difference $(p<0.05)$ was observed between the total densities of phytoplankton within the months during the study period. The highest cell density of $619.81 \pm 121.10$ cell/L (Figure 5(b)) phytoplanktonic species were observed in station 3 (ST3) and the lowest density of $264.07 \pm 85.63$ cell/L obtained in station 1 (ST1). There observed no significant difference ( $p>$ 0.05 ) between densities of phytoplankton within the station. 


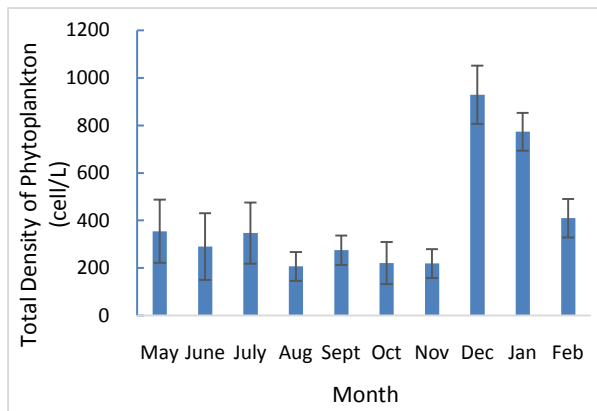

(a)

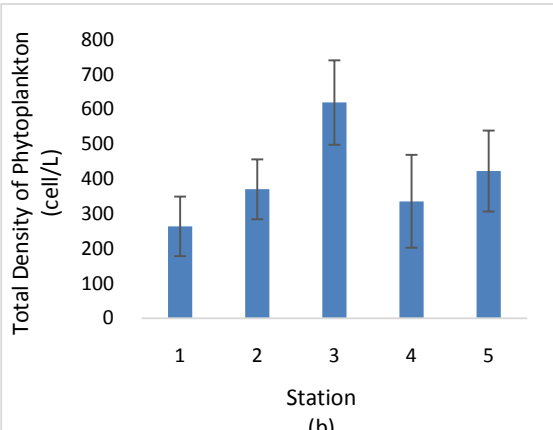

(b)

Figure 5. Temporal (5a) and spatial (5b) variations of phytoplankton density (cells/L) in Kudat's coastal water during study period of May 2019 to February 2020 (value of mean \pm sd.).

\section{Discussion}

\subsection{Temporal Variation in Physicochemical Water Parameters}

The significant differences $(p<0.05)$ were observed between all physio-chemical parameters within the months except for depth (m). Typically, low $\mathrm{pH}$ value of 7.33 was recorded during the month of Feb and slightly higher value of 8.20 observed in the month of November. The range of value indicated that the coastal ecosystem is suitable of aquatic life. The suitable range fish production within the range of 5.0 to 9.5 , as the run-offs into water due monsoon and other anthropogenic activities strongly influenced the amount of organic and will have profound influence on $\mathrm{pH}$ concentrations (Dan-kishiya et al., 2013). The high $\mathrm{pH}$ value (8.46) is due to the algae growth during that period, increasing the consumption of $\mathrm{CO}_{2}$ as part the photosynthesis process and consequently driving up the pH (Aknaf et al., 2017), but in this study no relationship was observed between the fluctuation of $\mathrm{pH}$ with the production of cell density. The extensive buffering capacity of the seawater with the tidal fluctuation may be the cause for a change in $\mathrm{pH}$ within a very narrow limit (Srinivasan \& Natesan, 2013).

Significant differences in monthly fluctuation in salinity were observed in the Kudat Coastal water. The changes are mainly because of monsoonal pattern in the study area. The highest of $32.37 \mathrm{ppt}$ and the lowest of $29.37 \mathrm{ppt}$ were recorded in the month of Nov to Jan and May to August respectively. Salinity mainly caused by dilution and evaporation process, influences the phytoplankton diversity in coastal ecosystem. Typically, changes in salinity in the brackish water habitats, such as estuaries, backwaters, and mangrove waters, are because of the influx of freshwater from land runoff caused by monsoon or tidal variations (Srinivasan \& Natesan, 2013). The low salinities were the consequence of higher river discharge from the surface runoff. In addition, tidal cycles influenced estuary with high salinity water and relatively weak vertical mixing, leading to an increase in the vertical salinity gradient (Xia et al., 2011).

The lowest concentration of dissolved oxygen of $4.02 \mathrm{mg} / \mathrm{l}$ in June 2019 and the highest of $6.71 \mathrm{mg} / \mathrm{l}$ were observed in September 2019. This could be attributed to the peak time of biochemical oxygen demand due to bacteria and other 
decomposers uptake during dry season. The low DO values in dry months were possibly due to considerable activities of microorganisms, which consumed appreciable amount of oxygen as a result of metabolizing activities and decay of organic matter (Eliku \& Leta, 2018). High dissolved oxygen values are probably due to the good oxygenation of the surface water as a consequence of the new uptakes of water, whereas the lower DO found in summer was due to the algal growth cessation and algal death, which consume dissolved oxygen (Aknaf et al., 2017). Dissolved oxygen content was high during monsoon season in the study area, which could be a result of the influx of freshwater during the monsoon season's higher solubility and low salinity (Prema \& Subramaniam, 2003). The concentration of $\mathrm{DO}$ and $\mathrm{pH}$ in any water body varies over time and is usually affected by other factors such as temperature, salinity and conductivity which are very important parameters that form the basis for an enlightened fisheries and water resources management (Araoye, 2009). In addition, the dissolved oxygen concentration is the resultants of the other factor, like rainfall, temperature, phytoplankton photosynthesis, and salinity in aquatic ecosystem.

The temperature was the lowest of $28.3^{\circ} \mathrm{C}$ and the highest of $31.5^{\circ} \mathrm{C}$ were observed in the month of January 2020 and May 2019 respectively. Seasonal variations in temperature can attribute with wind force, influx of freshwater and atmospheric temperature. The low temperature may be due to the heavy rainfall received during monsoon season. Decrease in water temperatures depends primarily on the rate of seasonal rainfall and lower air temperatures (Vajravelu et al., 2018). Temperature play significant roles in the aquatic ecosystem, which is one of the important parameters to control the physicochemical water The water temperature of the in this study area varied significantly among the month as regulated by the seasonal cycles of the air temperature as well down pour in particular locations. The regular seasonal cycle with minimum reached in January and a maximum in May and therefore did not appear to pose any threat in $\mathrm{Ku}$ dat coastal ecosystem.

Seasonal changes in depth during the study period were observed in the range of 2.6 to $3.7 \mathrm{~m}$ and not significantly different. In additional to tidal fluctuations, the depth also is affected by the seasonal pattern such as rainfall and surface runoff in coastal areas. The depth is important parameter that controls the penetration of light, which in turn accelerated photosynthesis activity and increase primary productivity of coastal ecosystem (Ibrahim et al., 2009). However, the rainfall data of this study was not collected, but cell density of phytoplankton clearly shows the productivity of Kudat coastal area with recorded depth.

\subsection{Spatial Variation in Physicochemical Water Parameters}

The highest $\mathrm{pH}$ value of 8.13 and the lowest of 7.86 were recorded in ST4 and ST2 respectively. $\mathrm{DO}$ and $\mathrm{pH}$, generally are influenced with photosynthesis, respiration and decomposition in aquatic ecosystem. The high $\mathrm{pH}$ value (8.46) is due to the algae growth and increasing the consumption of $\mathrm{CO}_{2}$ as part the pho- 
tosynthesis process and consequently increase the $\mathrm{pH}$ in aquatic substrate (Aknaf et al., 2017), but in this study the cell density was observed the highest at ST1, which shows no relationship in the increase in $\mathrm{pH}$ at ST 4. The low $\mathrm{pH}(7.86)$ at ST 3 might be due to algal mortality with high temperature, as the highest temperature was observed at ST 3, and might also be due to decomposition of organic matter generated from the cage culture activity in Kudat coastal area. The low $\mathrm{pH}$ value of 7.80 at station was explained by algal mortality period and the decomposition of plants and organic matter generated by eutrophication (Aknaf et al., 2017). The highest pH at ST 4 might also be due to drainage and other human activities, as well the concentration of nutrients. This station situated at the opening of river mouth, which might strongly influence the discharges from excessive land use and other human activities (Dan-kishiya et al., 2013).

The highest salinity of $31.29 \mathrm{ppt}$ and the lowest of $30.31 \mathrm{ppt}$ was determined from ST 4 and ST3 respectively. The increase in salinity was limited with the mixing or renewal of new water from the respective station. The highest salinity and electrical conductivity values found at station probably due to the shallowest depth of this station and to the low rate of water renewal in this site which is very fare from the inlet (Aknaf et al., 2017). Salinity was at a maximum (34.6 ppt) during monsoon season because of the opening of the mouth (Srinivasan \& Natesan, 2013). Salinity was the lowest of 30.31 at ST4 because there was minimum interaction of the sea with the estuary, as the depth observed the lowest of $2.0 \mathrm{~m}$, compare to $5.0 \mathrm{~m}$ at ST 2. Changes in salinity in the brackish water habitats, such as estuaries, backwaters, and mangrove waters, are because of the influx of freshwater from land runoff caused by monsoon or tidal variations (Srinivasan \& Natesan, 2013). The tidal cycles influenced estuary a high salinity in water assumed to be comparatively weak vertical mixing (Xia et al., 2011).

Dissolved oxygen concentration of coastal ecosystem related with primary productivity in particular location, which also is inversely related with the production of carbon dioxide in aquatic ecosystem. In addition to primary productivity saturation of dissolved oxygen in marine ecosystem is related to temperature, salinity, atmospheric pressure and oxygen demand from aquatic flora and fauna. Changes in dissolved oxygen can be an early indication of shifting conditions in the water body (Balance, 1996). Changes in dissolved oxygen can be an early indication of shifting conditions in the water body (Balance, 1996). The high concentration of dissolved oxygen values found at the location and was due to bloom of macro algae icluding Ulva lactuca Caulerpa prolefera and Gracilarea gracilis, characterized by high primary production due to photosynthesis and the minimum value of oxygen probably caused by the temperature rise which reduced the levels of dissolved oxygen and by Low rates of water renewal (Aknaf el al., 2017). In present study the highest concentration of DO was observed at ST 4 and at ST3, which was might be due to the highest density of phytoplankton recorded in respective station. On the other hand, the lowest dissolved oxygen of $4.33(\mathrm{mg} / \mathrm{L})$ was determined at ST 2 not due to related of phytoplankton density, but probably for other factors like microbial decomposition of organic matter, as 
the area near by Jetty and heavily utilised by the peoples. Dissolved oxygen is also controlled by various factors such as rainfall, temperature, and salinity. During the present study, salinity was not found to be the most important factor that controlled the level of dissolved oxygen in the coastal waters, as shows insignificant correlation with dissolved oxygen (Srinivasan \& Natesan, 2013).

Water temperature is the resultant of certain environmental factors and to the geographical location of the sampled stations. The temperatures were observed similar between sampling stations, with maximum of $30.6^{\circ} \mathrm{C}$ at ST 3 and the lowest of $30.3^{\circ} \mathrm{C}$ at ST 4 throughout the period of study which was probably due time of sampling as it dependent to presence of sunlight and heating effect. Here found no significant differences of temperature among the stations. Water temperature varied insignificantly with sampling stations so, did not appear to pose any threat to the aquatic system (Aknaf el al., 2017). The lowest temperature at ST 4 might be due to influences of renewal of new water from the river, as the station located near the mouth opening. However, the temperature on all stations was observed relatively homogeneous and favourable for the flora and fauna, as aquatic fauna (from microorganisms to fish) depend on certain temperature range for optimal growth.

\subsection{Phytoplankton Composition and Abundance}

A total of 21 phytoplankton were identified in this study during May 2019 to February 2020. Among them 18 species of phytoplankton were identified as diatoms which are the most dominant phytoplankton in this study area while 3 more species were dinoflagellates phytoplankton. Only three species of harmful alga blooming phytoplankton such as, Peridinium sp., Prorocentrum sp. and Dinophysis sp. were identified in the coastal water of Kudat, Sabah (Table 2). Overall, the total numbers of genera in Kudat coastal areas ( 24 genera) were observed relatively smaller compared to studies done by other researchers in tropical estuaries. As total of 24 species was identified at Kota Kinabalu wetland areas, mainly fluctuated with the tidal level (Azad \& Jinau, 2020). A total of 37 genera in Philippine mangrove estuary (Canini et al., 2013) and 30 genera in Sungai Brunei estuary (Majewska et al., 2017) indicated the lower diversity of phytoplankton at Kudat coastal areas. The environmental parameters such as temperature, salinity, Secchi depth (visibility), $\mathrm{pH}$, and dissolved oxygen are the factors that can affect the algal cells community succession or limit the growth of certain groups of algae (Hastuti et al., 2018). The three species belongs to HABs indicated that the area is not saturated with the nutrients generally that favour the growth of HAB species.

The highest cell density of $929.26 \pm 122.51$ (cell/L) and lowest total density of $206.67 \pm 60.11$ (cell/L phytoplankton was observed on August 2019 and December 2020 respectively (Figure 5). However, there were significant difference $(p<$ 0.05 ) was observed between the total mean density of phytoplankton and months during the study period. This could be due to monsoonal effects as heavy rainfall bringing nutrients to the study areas via river run-offs during 
rainy season (Soon \& Rangsangan, 2016). Phytoplankton communities are generally represented as an indicator in determining the changes of nutrients in water and as a vital component for evaluating eutrophication in marine ecosystems (Hastuti et al., 2018).

The highest total mean density of $619.81 \pm 121.10$ phytoplankton (cell/L) and the lowest of $264.07 \pm 85.63$ (cell/L was recorded at ST 3 and ST 1 respectively (Figure 5(b)). However, there is no significant difference $(p>0.05)$ between total mean density of phytoplankton and the sampled locations in this study. The highest density at ST 4 is probably due to release of metabolic waste products (faeces and excreta) and uneaten fish diet inside the cage area, which are enriched with nutrients that favour the growth of phytoplankton. The release of soluble inorganic nutrients (nitrogen and phosphorus) has a potential for phytoplankton growth and blooming (FAO, 1992). It is also caused by the effect of the coastal current and mixing action between offshore seawater and dilution of rivers (Huang et al., 2004). Due to seasonal and temporal changes, the distribution and abundance of phytoplankton in tropical waters vary greatly. Because of different environmental utilization strategies, the occurrence and succession of species in phytoplankton communities are usually caused by resource competition. That the higher nutrient concentrations are related to various hydrological factors (Srichandan et al., 2019).

The composition, abundance and growth of phytoplankton species are mainly affected by the physical and chemical parameters of the specific marine environment in which they are located (Vajravelu et al., 2018). In the estuarine environment, productivity primarily depends on phytoplankton, which alone contributes approximately $90 \%$ of the total estuarine primary production (Srinivasan \& Natesan, 2013).

\section{Conclusion}

The temporal and spatial distribution of physicochemical water quality is significantly different between the stations and months except for depth. Among the 21 phytoplankton species found in the Kudat's coastal water, only 3 are HAB namely, Peridinium sp., Prorocentrum sp. And Dinophysis sp. indicates the presence of insufficient amount of nutrients in the ecosystem. Not only man-made stressors might have an impact on the distribution of water quality parameters and that affected the abundance of phytoplankton in the study area. These data might be used as criteria for future research in water quality parameters of coastal areas. Besides that, continuous monitoring of other water quality like nutrient and hydrodynamics profiling necessary to achieve for better management of healthy ecosystem in coastal areas.

\section{Acknowledgements}

This research was fully funded by UMS Great (GUG032-1/2019) and Projek perlaksanaan Penyelidikan Inisiatif Segi Tiga Terumbu Karang (SDK0031-2018). 
The staff from BMRI laboratory are greatly acknowledged. Special thanks to the community of Kudat, especially the villagers from Landung Ayang Water Village, staff of Sabah Port SDN BHD and Marina Resort for their assistance throughout the sampling period.

\section{Conflicts of Interest}

The authors declare no conflicts of interest regarding the publication of this paper.

\section{References}

Aknaf, A., Akodad, M., Moumen, A., Ben Chekroun, K., Elhamouti, C., Bailal, A., \& Baghour, M. (2017). Study of the Spatial and Temporal Variation of Physical-Chemical Parameters Characterizing the Quality of Surface Waters of the Lagoon MarchicaNorth-East Morocco. Journal of Materials and Environmental Sciences, 8, 3216-3225.

Aktan, Y., Tufekci, V., Tufekci, H., \& Aykulu, G. 2005). Distribution Patterns, Biomass Estimates and Diversity of Phytoplankton in İzmit Bay (Turkey). Estuarine, 64, 671-684. https://doi.org/10.1016/j.ecss.2005.03.003

Araoye, P. A. (2009). The Seasonal Variation of $\mathrm{pH}$ and Dissolved Oxygen $\left(\mathrm{DO}_{2}\right)$ Concentration in Asa Lake Ilorin, Nigeria. International Journal of Physical Sciences, 4, 271-274.

Azad, S. A., \& Jinau, V. J. (2020). Spatial Distribution of Dissolved Inorganic Nutrients and Phytoplankton around Kota Kinabalu Wetland, Sabah, Malaysia. Advances in Biological Chemistry, 10, 113-126. https://doi.org/10.4236/abc.2020.104009

Balance, R. (1996). Water Quality Monitoring: A Practical Guide to the Design and Implementation of Freshwater Quality Studies and Monitoring Programmes. E \& FN Spon.

Canini, N., Azanza, R. V., \& Metillo, E. (2013). Monsoon-Influenced Phytoplankton Community Structure in a Philippine Mangrove Estuary. Tropical Ecology, 54, 331-343.

Dan-kishiya, A. S., Olatunde, A. A., \& Balogun, J. K. (2013). Variation in the Concentration of Dissolved Oxygen (DO) and Hydrogen Ion ( $\mathrm{pH}$ ) at the Surface of a Tropical Reservoir: A Case study of Lower Usuma Reservoir in Bwari Abuja, Nigeria. American Journal of Research Communication, 1, 204-214.

Eliku, T., \& Leta, S. (2018). Spatial and Seasonal Variation in Physicochemical Parameters and Heavy Metals in Awash River, Ethiopia. Applied Water Science, 8, Article No. 177. https://doi.org/10.1007/s13201-018-0803-x

Food and Agriculture Organization of the United Nations (1992). Guidelines for the Promotion of Environmental Management of Coastal Aquaculture Development (122 p). Food and Agriculture Organization of the United Nations.

Hastuti, A. W., Pancawati, Y., \& Surana, I. N. (2018). The Abundance and Spatial Distribution of Plankton Communities in Perancak Estuary, Bali. Earth and Environmental Science, 176, Article ID: 012042. https://doi.org/10.1088/1755-1315/176/1/012042

Huang, H., Li, F., \& Zhang, X. (2004). A Primary Comparison of Water and Sediment Fluxbetween the Changjiang River and the Yellow River. Studia Marina Sinica, 46, 79-90.

Ibrahim, B. U., Auta, J., \& Balogun, J. K. (2009). An Assessment of the Physicochemical Parameters of Kontagora Reservoir, Naigeria. Journal of Pure and Applied Sciences, 2, 64-69. https://doi.org/10.4314/bajopas.v2i1.58462

Kennish, M. J. (2000). Practical Handbook of Estuarine and Marine Pollution. CRC Press. https://doi.org/10.1201/9781420038484 
Majewska, R., Adam, A., Mohammad-Noor, N., Convey, P., Stefano, M. D. \& Marshall, D. J. (2017). Spatio Temporal Variation in Phytoplankton Communities along a Salinity and $\mathrm{pH}$ Gradient in a Tropical Estuary (Brunei, Borneo, South East Asia). Tropical Ecology, 58, 251-269.

Prema, M., \& Subramaniam, B. (2003). Hydrobiological Parameters of Muttukadu Backwater of Bay of Bengal. Indian Hydrobiol, 6, 95-100.

Sharma, R. C., \& Tiwari, V. (2018). Phytoplankton Diversity in Relation to Physico-Chemical Environmental Variables of Nachiketa Tal, Garhwal Himalaya. Biodiversity International Journal, 2, 102-110. https://doi.org/10.15406/bij.2018.02.00052

Shekhar, T. S., Kiran, B. R., Puttaiah, E. T., Shivaraj, Y., \& Mahadevan, K. M. (2008). Phytoplankton as Index of Water Quality with Reference to Industrial Pollution. Journal of Environmental Biology, 29, 233-236.

Sin, Y., Wetzel, R. L., \& Anderson, I. C. (1999). Spatial and Temporal Characteristics of Nutrient and Phytoplankton Dynamics in the York River Estuary, Virginia: Analysis of Long-Term Data. Estuaries, 22, 260-275. https://doi.org/10.2307/1352982

Singh, K. P., Malik, A., Mohan, D., \& Sinha, S. (2004). Multivariate Statistical Techniques for the Evaluation of Spatial and Temporal Variations in Water Quality of Gomti River (India): A Case Study. Water Research, 3980-3992.

https://doi.org/10.1016/j.watres.2004.06.011

Soon, T. K., \& Ransangan, J. (2016). Effects of Environmental Conditions and Nutrientson the Occurrence and Distribution of Potentially Harmful Phytoplankton in Mesotrophic Water. Sains Malaysiana, 45, 865-877.

Srichandan, S., Baliarsingh, K. S., Prakash, S., Lotliker, A., Parida, C., \& Sahu, K. (2019). Seasonal Dynamics of Phytoplankton in Response to Environmental Variables in Contrasting Coastal Ecosystems. Environmental Science and Pollution Research, 26, 12025-12041. https://doi.org/10.1007/s11356-019-04569-5

Srinivasan, K., \& Natesan, U. (2013). Spatio-Temporal Variations in Water Quality of Muttukadu Backwaters, Tamilnadu, India. Water Environment Research, 85, 587-595. https://doi.org/10.2175/106143012X13560205144812

Stirling, H. P. (1985). Chemical and Biologicl Methods of Water Analysis for Aquaculturists. University of Stirling Institute of Aquaculture.

United States Environmental Protection Agency (1998). Water Pollution Control: 25 Years of Progress and Challenges for the New Millennium. EPA 833-F-98-003, Office of Wastewater, United States Environmental Protection Agency.

Vajravelu, M., Martin, Y., Ayyappan, S., \& Mayakrishnan, M. (2018). Seasonal Influence of Physico-Chemical Parameters on Phytoplankton Diversity, Community Structure and Abundance at Parangipettai Coastal Waters, Bay of Bengal, South East Coast of India. Oceanologia, 60, 114-127. https://doi.org/10.1016/j.oceano.2017.08.003

Xia, M., Craig, P. M., Wallen, C. M. Stoddard, A., Mandrup-Poulsen, J., Peng, M., Schaeffer, B., \& Liu, Z. (2011). Numerical Simulation of Salinity and Dissolved Oxygen at Perdido Bay and Adjacent Coastal Ocean. Journal of Coastal Research, 27, 73-86. https://doi.org/10.2112/JCOASTRES-D-09-00044.1

Zulkifly, S., Rosli, N. S., Lazim, N. N. F., \& Yong, C. (2020). Physico-Chemical Influence on the Diversity of Phytoplankton at Putrajaya Lake and Wetlands, Putrajaya, Malaysia. Malayan Nature Journal, 72, 153-163. 